\title{
Analysis of the evidence of efficacy and safety of over-the-counter cough medications registered in Brazil
}

\author{
Adriano Max Moreira Reis ${ }^{1, *}$, Albert Figueras ${ }^{2}$ \\ ${ }^{1}$ Ribeirão Preto College of Nursing, University of São Paulo and Department of Pharmaceutical Products, Faculty of \\ Pharmacy, Federal University of Minas Gerais, ${ }^{2}$ Foundation Catalan Institute of Pharmacology, Vall d'Hebron Hospital, \\ Autonomous University of Barcelona, Barcelona, Spain.
}

\begin{abstract}
The objective of this study was to analyze the level of evidence regarding the efficacy, effectiveness and safety of over-the-counter (OTC) cough medications registered in Brazil. The National Health Surveillance Agency database was used to identify the drugs. Clinical trials, systematic reviews, meta-analyses, and studies on safety were searched on the Medline baseline, the Cochrane Library and SIETES (System of Essential Information in Therapeutics and Health; database in Spanish). Most drugs (62.5\%) were sold as a fixed-dose combination of two or more drugs. Randomized clinical trials were found for only three drugs: bromhexine, dextromethorphan and guaifenesin. No clinical trials were found for fixed-dose combinations. Systematic reviews on Cochrane did not report any evidence in favor of or against the effectiveness of cough drugs. Efficacy is also unclear, especially regarding fixed-dose combinations. The evidence for the efficacy of OTC cough medications available in Brazil is poor due to the lack of quality studies. Pharmacovigilance of OTC cough medications should be encouraged.
\end{abstract}

Uniterms: Drugs/utilization studies. Cough. Drugs/nonprescription. Pharmacovigilance. Pharmacoepidemiology.

\begin{abstract}
O objetivo deste trabalho foi analisar o nível de evidências sobre a eficácia, a efetividade e a segurança dos medicamentos para tosse registrados no Brasil. A base de dados da Agência Nacional de Vigilância Sanitária foi empregada para identificar os medicamentos. Os ensaios clínicos, as revisões sistemáticas, as metanálises e os estudos de segurança foram pesquisados no Medline, the Cochrane Library e SIETES (Sistema de Informações Essenciais em Terapêutica e Saúde, base de dados em espanhol). A maioria dos medicamentos $(62,5 \%)$ eram comercializados como associação em dose fixa com dois ou mais fármacos. Ensaios clínicos randomizados foram encontrados apenas para três fármacos: bromexina, dextrometorfano e guaifenesina; para associações a dose fixa não foram encontrados ensaios clínicos. Revisões sistemáticas publicadas pela Cochrane não encontraram evidências favoráveis ou contrárias à efetividade dos medicamentos para tosse. Essa eficácia não é clara, especialmente a das associações a dose fixa. As evidências sobre a eficácia dos medicamentos para tosse isentos de prescrição disponíveis no mercado brasileiro são fracas, devido à falta de pesquisas de boa qualidade. A farmacovigilância de medicamentos para tosse isentos de prescrição deve ser incentivada.
\end{abstract}

Unitermos: Medicamentos/estudos de utilização. Tosse. Medicamentos/isentos de prescrição. Farmacovigilância. Farmacoepidemiologia.

\section{INTRODUCTION}

Acute cough is a common symptom, usually associated with viral and bacterial infections of the respiratory

*Correspondence: A. M. M. Reis. Faculdade de Farmácia, Universidade Federal de Minas Gerais, Bloco B Sala 3040. Av. Antônio Carlos 6627 Campus Pampulha - 31270-010 - Belo Horizonte - MG, Brazil. E-mail: amreis@farmacia.ufmg.br. tract, and is one of the most common reasons for seeking medical care services, especially in pediatrics (Schaefer et al., 2007; Kelley, Allen, 2007). The common cold and acute cough are important determinants of access to drugs for self-medication. The magnitude of such use is evidenced by studies showing that about 95 million units of pediatric drugs for coughs and colds are sold every year in the United States (Sharfstein et al., 2007). The sale of 
pediatric and adult cough medication represents a significant proportion of the pharmaceutical market in many countries (Morice, 2002; Sharfstein et al., 2007). In most countries, these pharmaceutical preparations are sold as over-the-counter (OTC) drugs, a category that includes the following therapeutic classes: cough suppressants, expectorants, and mucolytics (Sharfstein et al., 2007). In primary health care, physicians often prescribe these drugs as the first line of treatment for acute cough (Smith et al., 2008).

Since the 1980s, evidence about the efficacy and safety of acute cough drugs has been called into question in the literature (Smith et al., 2008; Woo, 2008; CDC, 2007; Heineck et al., 1998; Rozenfeld et al., 1989). In 2006, the American College of Chest Physicians published nine guidelines for treating acute cough, which do not recommend use of OTC drugs (Bolser, 2006). Another concern regarding cough medications is fixed-dose combinations because using two or more drugs in the same formulation, besides having no supporting therapeutic grounds or scientific evidence, increases the risk of adverse events (Woo, 2008; Cadime, 2000).

The National Health Surveillance Agency (Agência Nacional de Vigilância Sanitária -ANVISA) was established in the late 1990s and brought about significant changes in the regulatory process of medications for sale in Brazil. Nevertheless, the national market offers an excessive number of drugs, with a significant number of pharmaceuticals of questionable or zero value, which are commercialized in different drug dosage forms and packaging, in a context of high prevalence of self-medication (Rinovato, 2008; Osório-De-Castro, 2000). These market conditions, in addition to the aggressive marketing actions by the pharmaceutical industry, allow medications to be used inappropriately, which can cause iatrogenic diseases and lead to higher costs to users and the health system.

In Brazil, cough medications are classified as OTC drugs, as per the list regulated by Resolution RDC number 138, of 05/29/03 by ANVISA (Brasil, 2003). The studies that analyzed the quality of cough medications sold in Brazil were published before ANVISA was established (Heineck et al., 1998; Rozenfeld et al., 1989).

The objective of this study was to learn about the current situation with respect to cough medications registered in Brazil, analyze the evidence for these drugs' efficacy and safety, and discuss the risks associated to their sale as OTC drugs.

\section{METHODOLOGY}

This is a drug utilization study, which analyzes the supply for acute cough drugs using the ANVISA database for drugs and hemoderivatives. Drugs supply studies provide analysis of the therapeutic quality of the drugs available in a given country or region, based on information from the pharmaceutical products registration system or national catalogs (Laporte, Tognoni, 1993).

The first step of this investigation was to perform a bibliographic search of tertiary international pharmacotherapy sources to identify the cough drugs used in clinical practice. The review was performed using the Handbook of Nonprescription Drugs 14ed and Martindale: The Complete Drug Reference 34ed (Sweetman, 2005, Berardi, 2004). The cough medicines included in this study were single-drug preparations or combinations of cough suppressants, expectorants and mucolytics. The identified drugs were grouped according to the Anatomic Therapeutic Chemical Classification System (ATC) to sublevel 4 as follows: RO5CA - expectorants, RO5CB - mucolytics, R05DA-opium alkaloids, R05DB - other cough suppressants, R05FA - combination of opium derivatives and expectorants, and R05X - other combinations. The second step was to identify the common Brazilian name for the drugs based on the List of Common Brazilian Denominations (CBD, 2007; Brasil, 2007). The existence of the identified drugs was verified using the electronic database of "registered drugs and hemoderivative products" available on the ANVISA website. The ANVISA database used in the research was updated after 3/25/2002 (Brasil, 2008a). Drug registrations were first searched based on the CBD. If drugs did not have a $\mathrm{CBD}$, their names were translated to Portuguese to perform the search. Phytopharmaceuticals were searched using the scientific name of the botanic species from which the active substance is extracted. The search of the ANVISA database yielded information about the drug dosage form, drug combinations, and registered products. In this study, "formulation" refers to a single drug preparation or combination, apart from excipients. Drugs included in this study had registrations which were valid until May 2008.

The quality of the evidence of the drugs' efficacy and safety was determined through a bibliographic search on PUBMED, Cochrane Library and SIETES (System of Essential Information in Therapeutics and Health; database in Spanish). Studies were selected if they addressed the efficacy, safety, and effectiveness of drugs used for treating acute cough. Only drugs with medications registered in Brazil were included in the study. The information regarding the drugs' registration in the ANVISA database was listed using a data collection instrument. The information was then transferred to a database created using Epi Data 3.1. Double entry was used and the obtained database 
was validated and its consistency confirmed. Descriptive statistical analysis was performed using SPSS 15.0.

\section{RESULTS}

The therapeutic arsenal for treating acute cough identified in the pharmacology and therapeutic digests consisted of 107 drugs, 19 of which were active principles of medications registered in Brazil. There are 40 medication formulations registered in Brazil for cough treatment.

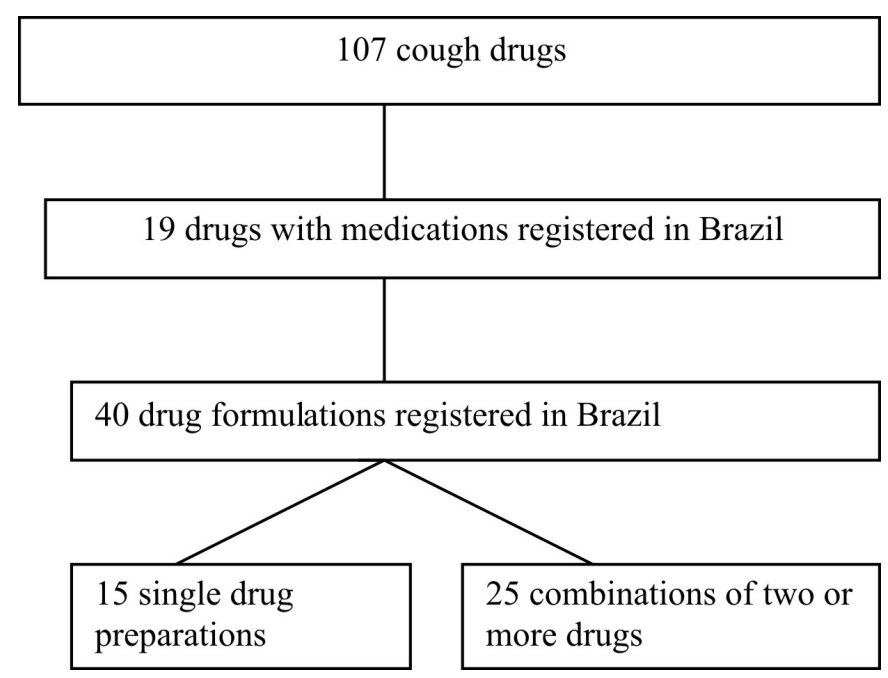

FIGURE 1 -Therapeutic arsenal for treating acute cough.

The classification of the cough drug formulations registered in Brazil according to ACT level 4 is presented in Table I.

The cough drug formulations registered in Brazil consisted of 25 (62.5\%) fixed-dose combinations and 15 $(37.5 \%)$ single drug preparations (Figure 1). Among the fixed-dose combinations, 8 (32\%) used two drugs and 17 $(68 \%)$ used more than two drugs.

With regard to the composition of the formulations, it was observed that $19(47.5 \%)$ were synthetic drug combinations, twelve (30.0\%) were synthetic single drug preparations, three $(7.5 \%)$ were phytopharmaceuticals, five $(12.5 \%)$ were combinations of phytopharmaceuticals and synthetic drugs and one $(2.5 \%)$ was a combination of multiple phytopharmaceuticals. The therapeutic classes of the fixed-dose combination drugs are presented in Table II, which shows there is a vast variety, with the expectorant guaifenesin appearing in the greatest number of pharmaceutical products as a component of combination formulations.

In terms of their drug dosage form, most (77.1\%) medications containing cough drugs were liquids. Other common drug dosage forms were lozenges and pills.

Table III shows the number of pharmaceutical products registered per formulation, regardless of the different presentations of each manufacturer. It is evident that most formulations $(23 ; 57.5 \%)$ had only one registered pharmaceutical products, and that nine formulations $(22.5 \%)$ had registers for over five medications.

The bibliographic search performed on PubMed found studies related to the treatment of acute cough that used five of the drugs registered in Brazil. The review on the Cochrane database found two clinical studies involving two of these drugs. On SIETES, in addition to clinical studies, drug surveillance warnings and a review of adverse reactions to dextromethorphan were found. The characteristics of the studies found on the cited databases

TABLE I - ATC sublevel 4 classification of cough treatment formulations registered in Brazil

\begin{tabular}{|c|c|c|}
\hline Classification and drugs & $\mathrm{N}$ & $\%$ \\
\hline $\begin{array}{l}\text { R05CA - Expectorants: } \\
\text { Glycyrrhiza glabra, Guaifenesin, Hedera helix } \\
\text { Potassium iodide, Mikania glomerata spreng., Potassium Sulfa Guayac }\end{array}$ & 6 & 15 \\
\hline $\begin{array}{l}\text { R05CB - Mucolytics: } \\
\text { Acetylcysteine, Ambroxol, Bromhexine, Carbocisteine }\end{array}$ & 4 & 10 \\
\hline $\begin{array}{l}\text { R05DA - Opium alkaloids: } \\
\text { Dextromethorphan }\end{array}$ & 1 & 2.5 \\
\hline $\begin{array}{l}\text { R05DB - Other cough suppressants } \\
\text { Clobutinol, Dropropizine, Cloperastine fendizoate, Levodropropizine }\end{array}$ & 4 & 10 \\
\hline $\begin{array}{l}\text { R05FA - Combination of opium derivatives and expectorants } \\
\text { Dextromethorphan Bromhydrate }+ \text { guaifenesin }\end{array}$ & 1 & 2.5 \\
\hline R05X - Other combinations & 24 & 60.0 \\
\hline Total & 40 & 100 \\
\hline
\end{tabular}


TABLE II - Types of fixed-dose combinations for cough treatments registered in Brazil

Types of combinations

Number of Registered Products

\section{Combinations with antihistamines}

Dextromethorphan Bromhydrate + Doxylamine succinate 1

Diphenhydramine hydrochloride + Ammonium chloride + Sodium citrate 2

Butamirate citrate + Oxeladin citrate + Diphenhydramine hydrochloride + Guaifenesin $\quad 1$

Clobutinol + Doxilamine $\quad 5$

Sodium dipyrone + Caffeine + Guaifenesin + Mepyramine maleate + Ascorbic acid 1

Teofilin + Guaifenesin +Pyridoxine +Diphenhydramine hydrochloride $\quad 1$

\section{Combinations with Adrenergic agents}

Guaifenesin + Dexchlorpheniramine maleate + Pseudoephedrine sulphate $\quad 5$

Pseudoephedrine hydrochloride + Guaifenesin 3

Dexchlorpheniramine maleate + Ephedrine sulphate + Guaifenesin $\quad 1$

Guaifenesin + Salbutamol sulphate $\quad 2$

Salbutamol sulphate +Guaifenesin +Sodium citrate $\quad 1$

\section{Combinations with Potassium Iodide}

Sodium benzoate + Oxomemazine hydrochloride+Guaifenesin +Potassium iodide + Fluid extract* 1

Guaifenesin + Potassium iodide 1

Potassium iodide + Potassium Sulfa Guayacolato + Myroxylon balsamum harms 1

Potassium iodide + Menthol 1

Potassium iodide + Guaifenesin + Menthol 1

\section{Combinations with Phytopharmaceuticals}

Menthol + camphor + eucalyptol +essence* + essence* $^{*}$ lamiaceae essence + turpentine essence $\quad 1$

tterpineol

Nasturtium officinale br.+ Aconitum napellus + Mikania glomerata spreng. + Polygala senega + 1

Cephaëlis ipecacuanha (brot) A.rich. + Myroxylon balsamum harm

Tiocholine + Sodium dibunate + Sodium benzoate + Fluid extract* + Fluid extract * + Aconitum 1

napellus extract

\section{Other Combinations}

Cetylpyridinium + Ammonium chloride + Sodium citrate + Sodium benzoate $\quad 1$

Ammonium chloride + Cetylpyridinium hydrochloride

* not specified on the ANVISA database

TABLE III - Number of registered pharmaceutical products per cough therapy formulation

\begin{tabular}{ccccc}
\hline $\begin{array}{c}\text { Number of registered } \\
\text { products }\end{array}$ & $\begin{array}{c}\text { Frequency Single drug } \\
\text { preparations }\end{array}$ & $\begin{array}{c}\text { Frequency } \\
\text { Combinations }\end{array}$ & Frequency Total & Percentage \\
\hline 1 & 5 & 18 & 23 & 57.5 \\
2 & - & 3 & 3 & 7.5 \\
3 & 1 & 3 & 4 & 10 \\
4 & 1 & - & 1 & 2.5 \\
$5-10$ & 4 & 1 & 5 & 12.5 \\
$11-20$ & 1 & - & 1 & 2.5 \\
Over 20 & 3 & - & 3 & 7.5 \\
\hline Total & 15 & 25 & 40 & 100 \\
\hline
\end{tabular}


TABLE IV - Types of publication on the efficacy, safety and effectiveness of cough drugs registered in Brazil identified on Cochrane, Medline and SIETES database systems

\begin{tabular}{|c|c|c|c|}
\hline$\overline{\text { Drug }}$ & Type of publication & Database & Author(s), year \\
\hline \multirow[t]{2}{*}{ Acetylcysteine } & $\begin{array}{l}\text { Observational study: } \\
\text { pharmacoepidemiological }\end{array}$ & Medline & Chalumeau et al., 2002 \\
\hline & Drug surveillance warning & SIETES & Anónimo, 1997 \\
\hline Ambroxol & $\begin{array}{l}\text { Observational study: } \\
\text { drug surveillance after } \\
\text { commercialization }\end{array}$ & Medline & Schulz et al., 2006 \\
\hline Carbocysteine & $\begin{array}{l}\text { Observational study: } \\
\text { Pharmacoepidemiological }\end{array}$ & Medline & Chalumeau et al., 2002 \\
\hline Guaifenesin & Randomized Clinical Trial & $\begin{array}{l}\text { Cochrane } \\
\text { Medline }\end{array}$ & $\begin{array}{l}\text { Kuhn ,1982 } \\
\text { Robinson et al., } 1977\end{array}$ \\
\hline \multirow[t]{4}{*}{ Dextromethorphan } & Randomized Clinical Trial & $\begin{array}{l}\text { Cochrane } \\
\text { Medline }\end{array}$ & $\begin{array}{l}\text { Tukiainem et al.1, } 1986 \\
\text { Taylor } \text { et al., } 1993 \\
\text { Lee et al., } 2000 \\
\text { Paul et al., } 2004 \\
\text { Paul et al., } 2007\end{array}$ \\
\hline & Meta-analysis & Medline & Pavezi, et al., 2001 \\
\hline & Randomized Clinical Trial & SIETES & Paul et al., 2007 \\
\hline & Literature Review & SIETES & Thanacoody, 2007 \\
\hline
\end{tabular}

are shown in Table 4. A meta-analysis of clinical trials with dextromethorphan (Pavezi, et al., 2001) was also found, in addition to four systematic reviews of clinical trials with general cough drugs (Smith et al., 2008; Schroeder, Fahey, 2002a; Schroeder, Fahey 2002b; Schroeder, Fahey, 2004 ). The Cochrane systematic review (Schroeder, Fahey, 2004) included a randomized clinical trial with bromhexine which was not identified in the electronic databases. No other clinical studies with the combinations registered in Brazil were found in the databases used in this study.

\section{DISCUSSION}

A variety of active principles are available for clinical use in cough drugs. In Brazil, the therapeutic arsenal includes 19 drugs, which correspond to $17.7 \%$ of the potential substances available in these groups, 15 of which are present in the formulations with a single active principle (Figure 1). The number of formulations (40) and the presence of nine formulations with more than five registers, three of which have more than twenty registers
(Table III), demonstrate the commercial importance of this group of medications, which represents a significant share of the pharmaceutical market according to estimates obtained in the United States (Sharfstein et al., 2007).

In the 1980s, the single-drug preparations for cough treatment sold in Brazil were identified in a study based on the Pharmaceutical Products Dictionary (Dicionário de Especialidades Farmacêuticas -DEF)and comprised 15 drugs. However, the number of drugs used in combinations was not stated. It is not possible to perform quantitative comparisons and evaluate the extent to which the availability of these drugs in the market has changed because this study used a different method for data collection that the present study. The national drug registration system is the most comprehensive for ascertaining the therapeutic arsenal because it is not economically biased. The DEF is a print publication and the availability of some information depends on payment from pharmaceutical industries (Schulz et al., 2006). Furthermore, the present study included phytopharmaceuticals, unlike the study performed in the 1980s. 
Regarding the therapeutic classes of the formulations registered in Brazil according to ATC level 4 (Table I), there is a prevalence of other combinations for cough treatment $(60.0 \%)$, but the following classes are also included: expectorants (15.0\%), mucolytics $(10 \%)$ and other cough suppressants (10\%). The most frequent type of combination involves synthetic drugs $(47.5 \%)$, but there are also combinations of phytopharmaceuticals and synthetic drugs $(12.5 \%)$ as well as phytopharmaceuticals $(2.5 \%)$.

There is much concern regarding the considerable number of drug combinations used for cough treatment, as literature reviews present no evidence supporting the use of any of the numerous combinations found on the Brazilian market (Tables I and II). On the other hand, it is known that the physiology of coughing contraindicates the use of any drugs containing cough suppressants combined with expectorants or mucolytics, since there is no justification for combining a cough reflex inhibitor with drugs that require that same reflex to be preserved for their pharmacological action to take place (Bolser, 2006).

The drug combinations for cough treatment need stronger grounds and evidence since they have not been evaluated through clinical trials with adequate internal and external validity to support their clinical use. The commercialization of these substances as OTC drugs promotes the false perception that they are safe and efficacious. Drug combinations and other cough drugs of different classes often contain antihistamines, iodides, adrenergic or antimicrobial agents in their formulations. The uncontrolled use of these combinations is not devoid of risk. For example, antihistamine agents can cause drowsiness and reduce one's ability to drive, whereas adrenergic agents can be dangerous in people with hypertension, hyperthyroidism, and coronary, cerebral, or peripheral artery diseases $(\mathrm{Ca}-$ dime, 2000). Iodides are associated with an array of side effects, with extra caution required in specific age groups (children, and women who are pregnant or breastfeeding). Iodides are contraindicated in tuberculosis and their use is supported by relatively weak evidence that does not justify their commercialization as expectorants or use in combination with nonprescription antitussive drugs (Rozenfeld et al., 1989). Another concern, especially in chronic use, is that these combinations can interact with other drugs that the patient might be using (Cadime, 2000).

The combinations of guaifenesin + pseudoephedrine and guaifenesin + pseudoephedrine + dexchlorpheniramine maleate occur in the formulations used in the greatest number of registered pharmaceutical products. No studies on their safety and effectiveness were found, but the studies by the Centers for Disease Control and Prevention on cough and cold drugs and emergency room visits identified deaths of children related to the use of pseudoephedrine in fixed-dose combinations (Sharfstein et al., 2007; CDC, 2007). The use of this drug is also associated with cardiac arrhythmias and other cardiovascular events (CDC, 2007). The availability of these over-the-counter combinations in the Brazilian market, which have no restrictions against use in children younger than two years, should be evaluated to assess the public health risks.

In Brazil, $77.1 \%$ of the registered cough drugs are sold in liquid form (Table II); this high incidence of liquid preparations, especially syrups, mirrors reports in other countries (Schulz et al., 2006). It was noted that $42.5 \%$ presently have a pending registry by more than one laboratory and some products have up to 20 pending registries (Table III). This data confirms the previous statement that the cough drug classification is of great commercial interest for the pharmaceutical industry.

Randomized clinical trials on acute cough treatment were identified only for dextromethorphan and guaifenesin (Table IV). A clinical trial for bromhexine was found among the studies included in the systematic review (Schroeder, Fahey, 2004). The methodological quality of the studies of this and other antitussive agents not sold in Brazil was evaluated in four published systematic reviews (Smith et al., 2008; Schroeder, Fahey, 2002a; Schroeder, Fahey, 2002b; Schroeder, Fahey, 2004). Reviews published in 2004 and 2008 on Cochrane included the meta-analysis of clinical trials of dextromethorphan performed by Pavesi et al., 2001.

The Cochrane reviewers stated that clinical studies conducted on nonprescription cough drugs present the following issues: small samples, inadequate masking strategies, lack of clarity of methods used to measure results, poor reporting of results, absence of placebo comparison, comparison of different therapeutic classes, and lack of uniformity in terms of cough duration in the patient inclusion criteria (Smith et al., 2008; Schroeder, Fahey, 2004 ).

In view of the quality of the clinical trials, the systematic reviews did not find any negative or positive evidence for indication of these drugs in acute cough. The 2008 version reiterates that their value in cough treatment remains inconclusive and confirms the lack of evidence for their effectiveness. It highlights the methodological limitations of the clinical trials performed on this drug class and suggests performing further studies to improve these aspects to better clarify the drugs' effectiveness and safety (Smith et al., 2008).

It is imperative that clinical trials of cough drugs be performed using a design that complies with quality clinical research practice, using validated instruments to evaluate cough and its consequences, so as to elucidate the efficacy of these drugs. These actions are important to 
avoid creating clinical guidelines based more on opinions than on evidence, as has occurred with guidelines published recently by the American College of Chest Physicians (Chung, 2007).

A clinical trial that evaluated dextromethorphan, honey and placebo in cough treatment in children (Paul et al., 2007) was published after the last systematic review. This study is notable because it provides new perspectives for cough treatment, since it found that honey was superior to Dextromethorphan or placebo in cough treatment in children with mild airway infections associated with sleep difficulties. Further studies are needed because the study in question was performed on a single day without complete double masking, and data collection was performed by the children's parents using a subjective questionnaire (Laporte et al., 2007). Eccles, in 2006, published physiologic explanations to justify the action of honey and other sweet substances on productive and dry coughs. The author used these probable action mechanisms to further infer that in liquid antitussive drugs, the sweet-tasting excipients were not inert and, therefore studies are unable to detect any significant difference in relation to placebos. Further studies with appropriate experimental models and supplemented with clinical trials performed based on quality clinical study practices can clarify this hypothesis and determine the therapeutic value of honey and other sweet substances on cough treatment.

The study of carbocisteine and acetylcysteine entailed an observational pharmacoepidemiological investigation performed with a sample of prescriptions by French pediatricians. It was found that $4.3 \%$ of prescriptions included mucolytic agents. The main indications were rhinopharyngitis, cough and acute bronchitis. Based on a literature review, the study concluded that the efficacy of these mucolytics in children was unclear. The study authors warned that the data from the French drug surveillance system indicated these drugs were unsafe in children due to the risk of paradoxical bronchoalveolar congestion (Chalumeau et al., 2002).

A post-marketing drug surveillance study involving 2664 participants selected at 266 German pharmacies evaluated the safety and utilization pattern of ambroxol syrup using a self-administered questionnaire. The adverse drug reaction (ADR) report rate was $2.5 \%$, and most adverse reactions were associated with the digestive system. No serious or unknown ADRs were reported. Ambroxol safety was considered very good by $51 \%$ of users and good by $46 \%$. Regarding its effectiveness, $29 \%$ considered it very good and $63 \%$ good, with $89 \%$ of users reporting they would use the drug again if needed. The study concluded that the use of OTC drugs can be controlled by pharmacies and that in Germany, ambroxol is used in compliance with the medicine package inserts. The study highlighted that the drug's safety and efficacy for acute bronchitis was confirmed (Schulz et al., 2006). The study has many methodological limitations, especially concerning the analysis, since it does not present the results according to the type of cough. In the discussion, the study stated that the product was used as a self-administered cough drug, but in the conclusion section it presented conclusions based exclusively on acute bronchitis. To justify the statement about the drug's safety and efficacy, the authors made reference to studies performed on patients with chronic respiratory system diseases. However, the fact that this study used patients' statements for adverse reaction reports remains controversial in terms of drug surveillance (Harmark, Grootheest, 2008).

The search on the SIETES database found publications on the safety of acetylcysteine and dextromethorphan. This particular database specializes in information on medications and contained drug surveillance warnings and studies not indexed on the PubMed database. These studies are important sources for the evaluation of the risk-benefit relationship of the drugs available on the market and are therefore relevant for studies on drug supply. The adverse reactions described in these studies can be serious, including hypersensitivity to acetylcysteine, and serotonergic syndrome after dextromethorphan (Anónimo, 1997; Thanacoody, 2007)

The results of the systematic reviews, the small number of observational studies, the reported adverse reactions, and the quality of the clinical trials call for a critical analysis of the classification of OTC drugs for acute cough treatment. This analysis should be performed considering the theoretical criteria that should support the approval of a drug for sale without a prescription. Strom (2005) identified important criteria to make the registration of OTC drugs feasible. First, the drug's safety and effectiveness should be well established. Another essential condition is to determine the efficacy of the self-diagnosed clinical condition. The drug should have a broad margin of safety established for a considerable number of individuals. The drug should have a low potential for abuse and low risk for inadequate use or drug interactions. Efficacy and safety should not depend primarily on the dose or frequency of administration. The drug should be safe for use by special populations such as pregnant women, aged individuals and children. The author presents supplementary criteria, mainly regarding patient information on self-diagnosis and self-treatment.

Drugs for acute cough do not meet the main criteria: safety and effectiveness for the symptoms that led to their use. In addition, these drugs do not have a broad margin 
of safety for a considerable number of individuals (Smith et al., 2008). Another flaw is the failure to establish the efficacy for the self-established clinical condition. In fact, the section in which the 2008 systematic review suggests further studies, carries a recommendation evidencing that this criterion was not met by the drug group. Dextromethorphan presented a potential for abuse, since it is used as a recreational drug, mainly among adolescents (Bryner, 2006; Falck, 2006; Paul et al., 2004). The profile of the adverse reactions to antitussive agents is widely discussed in the medical literature. Dextromethorphan in therapeutic doses can cause the following: dystonia, bullous mastocytosis and anaphylaxis while at high doses it can cause, among other reactions, hallucination, ataxia, psychosis, cerebral degeneration and peripheral neuropathy (Paul et al. , 2007). The safety of cough drugs in children less than two years of age is not yet well established, and the pediatric doses have been obtained by extrapolation from the adult doses (CDC, 2007). Emergency care provided to children less than twelve years of age due to adverse events associated with antitussive agents is an issue of concern in the United States (Schaefer et al., 2007). It is evident that cough drugs do not fully satisfy the minimum requisites for being sold over the counter.

The withdrawal of clobutinol from the market in several countries by its manufacturer, and the Food and Drug Administration (FDA) recommendation not to use antitussive and cold drugs in children younger than two years of age, are concrete actions of a pharmaceutical industry and regulating agency that show flaws in the registration of OTC drugs which potentially expose the population to risk (FDA, 2008). Clobutinol is associated with a risk of QT interval prolongation which can cause cardiotoxicity (WHO, 2008). The flawed nature of OTC drug registration became more evident when it was verified that generic clobutinol is still sold in Brazil despite the reference drug being withdrawn from the market. The restriction on the use of antitussive agents in children younger than two years was motivated by the absence of any evidence of its efficacy, a lack of consensus on the pediatric dose, and the risks associated with morbidity and mortality in this age group (CDC, 2007; Irwin, 2007). The technical reports announced on the ANVISA website do not include any warnings restricting the use of cough drugs in children younger than two years (Brasil, 2008b).

In the light of these flaws in the criteria for registering OTC drugs, it is important to know the therapeutic value of the drugs available on the country's market. An analysis of the main OTC drugs sold in Brazil in the 1990s showed that $91 \%$ had poor intrinsic value. The sample included antitussive agents and expectorants, which were classified as having little or no value (Heineck et al., 1998). A study on cough drugs found there was a lack of scientific evidence regarding their efficacy coupled with a high rate of drug combinations (Smith et al., 2008). These characteristics are similar to drugs currently registered in Brazil. In view of these conditions and the culture of self-administration, it is essential to implement measures to improve the registration process as well as the drug surveillance actions aimed at OTC drugs. The reporting pharmacies program under development by ANVISA is a step toward making drug surveillance practices feasible in this drug group.

Health surveillance actions related to drug management should be grounded in scientific studies that evaluate the collective risk-benefit. This practice can contribute to the quality of the drug registration process and the monitoring of the safety of pharmaceutical products sold in Brazil. Therefore, the results of studies on cough drugs, especially those published by the CDC (2005) and Cochrane (Smith et al., 2008) indicate the need for ANVISA to reevaluate the decision of maintaining these drug groups on the Brazilian market, considering the riskbenefit relationship. A review on the registrations of cough drugs, especially combinations, is essential to guarantee the availability of safe and effective pharmaceuticals on the national market.

The development of educational material on strategies to cope with acute cough for the lay population, as well as the dissemination of information to prescribers about the scientific evidence regarding treatment, are measures that contribute toward the safe use of these drugs.

One limitation of the present study was the use of a database that provides information exclusively for registered drugs. Therefore, it cannot be stated that all these drugs are currently available on the Brazilian market. However, it is possible to gain insights into the qualitative profile of registered drugs and, indirectly, about the fragility of the criteria used for registration. Further studies, using private databases specialized for the pharmaceutical market, or other ANVISA databases, will enable identification of the drugs that are truly being sold in Brazil as well as their economic relevance.

In addition, further studies available on the ANVISA adverse drug reactions database and the national poisoning information system can improve knowledge about the safety profile of these drugs in Brazil.

\section{CONCLUSION}

The efficacy and effectiveness of cough drugs available on the Brazilian market is poorly supported 
by weak evidence. There is much concern regarding the considerable number of combined preparations containing antitussive agents and over the lack of restrictions on the use of these drugs in children under two years of age. To summarize, there is no evidence supporting the recommendation of these drugs as the first-line treatment for acute cough associated with upper respiratory tract infections.

The intrinsic therapeutic value of drugs sold in Brazil is similar to that of drugs available in the late 1980 s, which suggests that the new registration systems implemented in the country through ANVISA did not affect the qualitative profile of this drug group.

The present study on drug supply provides information about the profile of drugs used for cough treatment registered in Brazil, and on the implementation of regulatory and educational measures with a view to assuring the rational use of these drugs. The study results also highlight the need to reevaluate the registration criteria for OTC drugs, with the purpose of guaranteeing that individuals who choose self-medication have access to safe and effective drugs. It is essential to make pharmacovigilance actions feasible for OTC drugs in order to establish the risk-benefit relationship of this therapeutic class.

\section{REFERENCES}

ANÓNIMO. Reacciones anafilácticas a $\mathrm{N}$-acetylcysteine. Boletín de Farmacovigilancia de la Comunidad Valenciana, v.38, p.561-562, 1997. Available at: $<$ http://www.sietes.org. es>. Accessed on: 20 mai. 2008.

BRASIL. Agência Nacional de Vigilância Sanitária. RDC nº 128 de 29 de maio de 2003. Available at: $<$ http://e-legis.anvisa. gov.br/leisref/public/showAct.php?id=16672\&word=>. Accessed on: 05 mai. 2008.

BRASIL. Agência Nacional de Vigilância Sanitária. Lista da Denominação Comum Brasileira 2007. Available at: $<$ http://www.anvisa.gov.br/medicamentos/dcb/lista dcb_2007.pdf $>$. Accessed on: 05 mai. 2008.

BRASIL. Agência Nacional de Vigilância Sanitária. Produtos Registrados das Empresas de Medicamentos e Hemoderivados. Available at : <http://www.anvisa.gov.br/ datavisa/Consulta_Produto/consulta_medicamento.asp. >. Accessed on: 25 abr. 2008.

BRASIL. Agência Nacional de Vigilância Sanitária. ANVISA publica informes técnicos Available at : <http://www. anvisa.gov.br/divulga/informes/index.htm $>$. Accessed on: 25 mai. 2008.
BERARDI, R. Handbook of nonprescription drugs: an interactive approach to self-care. 14.ed. Washington: American Pharmacists Association, 2004. 1370 p.

BOLSER, D. C. Cough suppressant and pharmacologic protussive therapy. ACCP evidence-based clinical practice guidelines. Chest, v.129, suppl.1, p.238S-249S, 2006.

BRYNER J. K.; WANG, U. K.; HUI, J. W.; BEDODO, M.; MACDOUGALL, C.; ANDERSON IB. Dextromethorphan abuse in adolescence: an increasing trend: 1999-2004. Arch. Pediatr. Adolesc. Med., v.160, n.12, p.1217-1222, 2006.

\section{CENTERS FOR DISEASE CONTROL AND PREVENTION}

-CDC. Infants deaths associated with cough and cold medications -two states, 2005. Morb. Mortal Wkly Rep, v.56, n.1, p.1-4, 2007.

CENTRO ANDALUZ DE INFORMACIÓN DE MEDICAMENTOS-CADIME. Antitusígenos: uso racional en adultos y niños. Bol. Ter. Andal., v.16, n.6, p.22-22II, 2000.

CHALUMEAU, M.; CHÉRON, G.; ASSATHIANY, R.; MOULIN, F.; BAVOUX, F.; BRÉART, G.; PONS, G. Mucolytic agents for acute respiratory tract infections in infants: a pharmacoepidemiologic problem? Arch. Pediatr., v.9, n.11, p.1128-1136, 2002.

CHUNG, K. F. Effective antitusives for the cough patient: an unmet need. Pulm. Pharmacol. Ther., v.20, n.4, p.438445,2007 .

ECCLES, R. Mechanisms of the placebo effect of sweet cough syrups. Respir. Physiol. Neurobiol., v.152, n.3, p.340-348, 2006.

FALCK, R.; LI, L.; CARLSON, R.; WANG, J. The prevalence of dextromethorphan abuse among high school students. Pediatrics, v.118, n.5, p.2267-2269, 2006.

FOOD AND DRUG ADMINISTRATION. FDA recomendeds that over-the-counter(OTC) and cold products not be used for infants and children under 2 years of age. Available at : $<$ http://: www.fda.gov/cder/whatsnew.htm> Accessed on: 12 mai. 2008.

HARMARK, L.; GROOTHEEST, A. C. V. Pharmacovigilance: methods, recent developments and future perspectivas. Eur. J. Clin. Pharmacol., v.64, n.8, p.743-752, 2008. 
HEINECK, I.; SCHENKEL, E. P.; VIDAL, X. Medicamentos de venta livre en el Brasil. Rev. Panam. Salud Publica., v.3, n.6. p.385-391,1998.

IRWIN, K. A. Use of over-the-counter cough and cold medications in children younger than 2 years. J. Pediatr. Health Care., v.21, n.4, p.272-275, 2007.

KELLEY, L. K.; ALLEN, P. J. Managing acute cough in children: evidence-based guidelines. Pediatr. Nurs., v.33, n.3, p.515-524, 2007.

KUHN, J. J. et al. Antitussive effect of guaifenesin in young adults with natural colds objective and subjective assessment. Chest, v.82, n.6, p.713-718, 1982.

LAPORTE, J. R.; TOGNONI, G. Estudios de utilización de medicamentos y de farmacovigilancia. In: Principios de epidemiologia del medicamento. 2.ed. Barcelona: Masson Salvat, 1993. cap.1, p.1-24.

LAPORTE, J. R.; LLOP, R.; BOSCH, M. Actualització en Farmacología Available at: <http://www.icf.uab.es/ informacion/update_jam/Update/UPDATE2007.pdf. $>$. Accessed on: 12 mai. 2008.

LEE, P. C. L.; JAWAD, M.C.; ECCLES, R. Antitussive efficacy of dextromethorphan in cough associated with acute upper respiratory tract infection. J. Pharm. Pharmacol., v.52, p.1137-1142, 2000.

MORICE A H. Epidemiology of cough. Pulm. Pharmacol. Ther, v.15, n.3, p.253-259, 2002.

OSÓRIO-DE-CASTRO, C. G. S. Estudo de utilização de medicamentos - noções básicas. Rio de Janeiro: Fiocruz, 2000. 92 p.

PAVEZI, L.; SUBBURAJ, S.; PORTER-SHAW, K. Application and validation of a computerized cough acquisition system for objective monitoring of acute cough. A meta-analysis. Chest., v.120, n.4, p.1121-1128, 2001.

PAUL, I. M.; YODER, K. E.; CROWELL, K. R.; SHAFFER, M. L.; MCMILLAN, H. S.; CARLSON, L. C.; DILWORTH, D. A.; BERLIN, C. M . Effects of dextromethorphan, diphenydramine, and placebo on nocturnal cough and sllep quality for coughing children and their parents. Pediatrics, v.114, n.1, p.85-90, 2004.
PAUL, I. M.; BEILER, J.; MCMONAGLE, A.; SHAFFER, M L.; DUDA, L.; BERLIN, C. M. Effects of honey, dextromethorphan, and no treatment on nocturnal cough and sleep quality for coughing children and their parents. Arch. Pediatr. Adolesc. Med., v.161, n.12, p.1140-1146. 2007.

PUJET, J. C.; KEDDAD, K.; SÉVENIER, F.; JOLIVETLANDREAU, I.;PUJET, J. C. Comparative study of two antitussive drugs in the treatment of acute dry cough of infectious origin (prospective, randomized, single blind study). Therapie, v.57, n.5, p.457-463, 2002.

RINOVATO, R. D. O uso de medicamentos no Brasil : uma revisão crítica. Rev. Bras. Farm., v.89, n.1, p.64-69, 2008.

ROBINSON, R. E; CUMMINGS, W. B.; DEFFENBACH, E. R. Effectiveness of guaifenesin as an expectorant: a cooperative double-blind study. Curr. Ther. Res., v.22, n.2, p.284-296, 1977.

ROZENFELD, S.; SPICLER, E.; RANGEL, I. T. M.; RODRIGUES, M. F.; PEPE, V. L. E. Avaliação crítica da terapia da tosse. J. Pediatr., v.65, n.8, p.315-324,1989.

SCHAEFER K. M.; SHEHAB, N.; COHEN, A. L.; BUDNITZ, D. S.; Adverse events from cough and cold medications in children. Pediatrics, v.121, n.4, p.783-787, 2008.

SCHROEDER, K.; FAHEY, T. Should we advise parents to administer over the counter medications for acute cough? Systematic reviews of randomized control trials. Arch. Dis. Child., v.86, n.3, p.170-175, 2002.

SCHROEDER, K.; FAHEY, T. Systematic reviews of randomized control trials over the counter medications for acute cough in adults. BMJ., v.324, n.7333, p.1-6, 2002.

SCHROEDER, K. F. T. Over-the- counter medications for acute cough in children and adults in ambulatory settings. Cochrane Database Syst. Rev., v.1, n.4, CD001831, 2004.

SCHULZ, M.; HÄMMERLEIN, A.; HINKEL, U.; WEIS, G.; GILLISSEN, A. Safety and usage pattern of an over the counter ambroxol cough syrup: a community pharmacybased cohort. Intern. J. Clin. Pharmacol. Ther., v.44, n.9, p.409-421, 2006.

SHARFSTEIN, J. M.; NORTH, M.; SERWINT, JR. Over the counter but no longer under the radar pediatric cough and cold medications. N. Engl. J. Med., v.357, n.23, p.23212324. 
SMITH, S. M., SCHROEDER, K.; FAHE, T. Over-the-counter medications for acute cough in children and adults in ambulatory settings. CochraneDatabase of Syst. Rev. v.1, n.1, CD001831, 2008.

STROM, B. L. Over- the -counter availability of statins. N. Engl. J. Med., v.352, n.14, p.1403-1405, 2005.

SWEETMAN, S. C. Martindale: the complete drug reference. 34.ed. London: Pharm Press, 2005. 2756 p.

TAYLOR, J. A; NOVACK, A. H.; ALMQUIST, J. R.; ROGERS, J. E. Efficacy of cough suppressants in children. J Pediatr., v.122, n.5, p.799-802. 1993.

THANACOODY, R. H. K. Serotonin syndrome. Adv. Drug React. Bull., Newcastle Upon Tyne, v.243, n.4, p.931-934, 2007.

TUKIAINEN, H.; KARTTUNEN, P.; SILVASTI, M.; FLYGARE, U.; KORHONEN, R.;KORHONEN. T,.;MAJANDER ,R.; SEURI, M. The treatment of acute transient cough: a placebo-controlled comparison of dextromethorphan and dextromethorphan-beta 2-sympathomimetic combination. Eur. J. Respir. Dis., v.69, n.2, p.95-99, 1986.
VERNACCHIO, L.; KELLY, J.P.; KAUFMAN, D.W.; MITCHELL. A.A. Cough and cold medication use by US children, 1999-2006: results from the slone survey. Pediatrics, Springfield, v.122, n.2, p.323-329, 2008.

WEIPPL, G. Therapeutic approaches to the common cold in children. Clin Ther, v.6, n.4, p.475-482, 1984.

WOO, T. Pharmacology of cough and cold medicines. J. Pediatr. Health Care.,v.22, n.2, p.73-79, 2008.

WORLD HEALTH ORGANIZATION. Voluntary withdrawal of clobutinol cough syrup. WHO Drug Information, v.22, n.1, p.22, 2008.

Received for publication on $03^{\text {rd. }}$ December 2008 Accepted for publication on $12^{\text {th }}$ November 2009 
